\title{
Australian Journal of

\section{Micrometeorological methods to estimate sugarcane evapotranspiration in coastal northeastern region of Brazil}

\author{
Adolpho Emanuel Quintela da Rocha*1, José Leonaldo de Souza ${ }^{2}$, Guilherme Bastos Lyra ${ }^{2}$, Ricardo Araújo \\ Ferreira Junior ${ }^{2}$, Gustavo Bastos Lyra ${ }^{3}$, Laurício Endres ${ }^{4}$, Marshall Victor Chagas Santos ${ }^{1}$
}

${ }^{1}$ Department of Agricultural Engineering, Federal University of Viçosa, Viçosa-MG, Brazil

${ }^{2}$ Department of Agrometeorology, Federal University of Alagoas, Maceió-AL, Brazil

${ }^{3}$ Department of Meteorology and Climatology, Federal Rural University of Rio de Janeiro, Seropédica-RJ, Brazil

${ }^{4}$ Plant Physiology Laboratory, Federal University of Alagoas, Center of Agronomy, Maceió-AL, Brazil

\section{*Corresponding author: adolphoquintela@hotmail.com}

\section{Abstract}

The aim of the present work was to evaluate the performance of Bowen ratio-energy balance method, as well as the energy balance closure by Eddy covariance technique for a sugarcane crop in Brazilian northeastern region. Micrometeorological measurements were carried out between June 7th and November 17th, 2013. Latent and sensible heat fluxes were determined through Eddy covariance technique (EC) and by the Bowen ratio-energy balance method (BREB), considering two approaches. The first, estimated the air temperature and water vapour pressure gradient in two levels above the canopy. The second method measured the air temperature and water vapour pressure at the first level and the surface temperature from radiometric measurements. Latent heat flux was also estimated as energy balance residue from determinations of the sensible heat flux by Eddy covariance. The degree of energy balance closure was dependent on the time of the day considered. Bowen ratio - energy balance estimated from the first approach, showed the best agreement with the eddy covariance measurements to estimate latent heat flux, while in the second case, when the Bowen ratio was estimated using the surface temperature, the linear relationship was the most discrepant. Therefore, the Bowen ratio conventional method is more suitable for estimating latent heat flux in sugarcane.

Keywords: eddy covariance, Bowen ratio, energy balance, Saccharum spp.

Abbreviations: ET_Evapotranspiration; NEB_Northeastern Brazil; EC_Eddy Covariance Technique; BREB_Bowen ratio - energy balance; EBC_Energy balance closure; BREB_S_Bowen ratio - energy balance method with surface temperature, EC_R_residual eddy covariance technique

\section{Introduction}

The understanding of the biophysical processes that occur in the soil-plant-atmosphere system is critical for the determination of water needs and definition of management techniques in agricultural systems. Considering that water is a resource in great demand and that laws regulate its use, crop evapotranspiration (ET) is one of the variables of major interest in agriculture, especially in regions where the resource is a limiting factor (Jabloun and Sahli, 2008), like in Northeastern Brazil (NEB).

In NEB, sugarcane (Saccharum spp) is one of the major crops and its production is restricted by the temporal-spatial heterogeneity of rainfall, in addition to the fact that the period of higher (lower) solar radiation coincides with lower (greater) water availability (Silva et al., 2013, Teodoro et al., 2015). Thus, the use of irrigation complementing rainfall is necessary to reach high yields.

The use of irrigation requires the correct determination of the crop water requirement for the rational use of water resources. ET can be quantified by means of approaches based on water balance, micrometeorological techniques and plant transpiration (Wilson et al., 2001). Micrometeorological techniques are widely used. However, their use is restricted to research for the validation of methods that are simple to use and adequate to the climatic conditions of each region (Liu et al., 2012; Er-Raki, et al., 2013). Among the micrometeorological methods, the Bowen ratio - energy balance (BREB) is widely used to estimate $E T$ due to its simplicity. However, BREB has some problems associated with measurements of net radiation ( $\mathrm{Rn})$ and air temperature and humidity gradients, which results in invalid or inconsistent estimates (Ohmura, 1982; Silva et al., 2012). BREB is commonly used in studies to estimate sugarcane ET (Silva et al., 2015; Nassif et al., 2014); however, due to the inherent problems of this method, other approaches and modifications such surface temperature from radiometric measurements can be used to improve the results (Lhomme et al., 1994; Norman et al., 2000). The validation of BREB to estimate ET has been performed considering as standard the measurements obtained by the Eddy covariance technique $(E C)$. The principle of EC is to determine the average 
covariance between vertical wind fluctuations and air temperature or water vapour concentration to obtain sensible $(H)$ or latent heat fluxes $(\lambda E)$, respectively (Baldocchi, et al., 1988; Baldocchi, 2003). However, this method also presents a series of uncertainties resulting from unsatisfied assumptions and the chaotic nature of turbulence (Mauder et al., 2013), which results in discrepancy between available energy and heat fluxes ( $\lambda E$ and $\mathrm{H}$ ). In this case, the energy balance closure might be required (Twine et al., 2000).

According to the above, the aim of the present work was to evaluate the performance of BREB, as well as the energy balance closure by EC measurements under a sugarcane crop in the coastal region of the state of Alagoas, Northeastern Brazil.

\section{Results and discussion}

\section{Energy balance closure}

The description of the environmental conditions as well as the daily patterns of the energy fluxes as a function of the meteorological conditions are described in Rocha et al. (2018). Therefore, in the present study the results will concentrate on discussing the estimation methods of energy balance components in sugarcane by micrometeorological technique. EBC by EC was assessed on daytime scale and during morning and afternoon shifts. The daytime index was $64 \%$ (Fig. 1A); during the morning 57\% (Fig. 1B), and during the afternoon the value was maximum (76\%) (Fig. 1C). The non-closure of the energy balance with the EC technique has been reported in several studies. Wilson et al. (2002) analyzed EBC from several measurement environments of the FluxNET research network and reached an average value of $80 \%$, with higher index during the afternoon. This characteristic was attributed to the underestimation of storage terms, as heat retention in biomass, which are higher during the morning. The discrepancy between the Rn - $G$ and $\lambda E+H$ relationship was also observed in other crops, such as cotton (0.76), potato (0.79) and maize (0.81) (Chavez et al., 2009; Parent and Anctil, 2012; Ding et al., 2010).

Achieving complete energy balance closure is not possible from experimental data (Foken et al., 2006). When it comes to the EC, the causes for discrepancy between energy availability and output fluxes are attributed to the occurrence of advection, loss of low frequency components, instrument limitations, heat retention in crop biomass and neglect of other energy balance terms (Barr et al., 1994; Meyers and Hollinger, 2004; Oncley et al., 2007; Li et al., 2005). Thus, when EBC by EC is not satisfactory, it is recommended to calculate $\lambda$ by the relationship between $\lambda \mathrm{E}$ and $\mathrm{H}$ obtained by $\mathrm{EC}$, and to recalculate both fluxes by means of equations 2 and 3, respectively (Twine et al., 2000; Steinwand et al., 2006; Sànchez et al., 2009). The adoption of energy balance closure by the Bowen ratio has been adopted for sugarcane, including for EBC higher than the present study, such as $<70 \%$ in Sertãozinho, Brazil (Cabral et al., 2003) and $80 \%$ in Xicoténcat, Mexico (Zermeño-Gonzalez et al., 2012). Hence, the data referring to $\lambda E$ discussed in the present work will come from the energy balance closure by the previously described method.
After energy balance closure by the Bowen ratio $(\lambda)$, we observed that $63 \%$ of the available energy $(R n-G)$ was used in the evapotranspiration process $(\lambda E)$, while the remaining $37 \%$ were used to heat up the air (H) (Fig. 2A). The use of most of $\mathrm{Rn}-\mathrm{G}$ by $\lambda E$ was due to the soil water availability resulting from the various precipitation events during the measurement period, which did not limit the evapotranspiration process during most of the evaluation period. When considering the partitioning of available energy by the EC_R method, $76 \%$ of energy was consumed by $\lambda E$ and $24 \%$ for $H$ (Fig 2B). The BREB method was the one that most approached the $\mathrm{EC}$, with $66 \%$ for $\lambda \mathrm{E}$ and $34 \%$ for $\mathrm{H}$ (Fig. 2C). BREB_S presented the greatest discrepancy in relation to $E C$, with $91 \%(\lambda E)$ and $9 \%(H)$ (Fig. 2D).

When BREB was used in sugarcane under full irrigation, Silva et al. (2011) observed that $81 \%$ of Rn-G observed for $\lambda E$, while the remaining $19 \%$ for $\mathrm{H}$. Using the BREB method in sugarcane in coastal tablelands of Paraíba, Brazil, Azevedo et al. (2014) reported that $82 \%$ of $R n$ was consumed by $\lambda E$, while $\mathrm{H}$ and $\mathrm{G}$ consumed $16 \%$ and $2.0 \%$, respectively.

The BREB and EC_R methods showed the lowest RMSE, 61.1 and $77.1 \mathrm{~W} \mathrm{~m}^{-2}$, respectively, while the BREB_S had the highest, $130.9 \mathrm{~W} \mathrm{~m}^{-2}$. The "d" followed the same RMSE pattern, with the highest index for the BREB method (0.97), followed by the EC_R (0.96) method and lower for the BREB_S (0.90) method. In general, according to the slope (b), the tendency of the BREB method was to overestimate $\lambda E$ determined by EC by approximately $6 \%$. The EC_R and BREB_S methods also showed an overestimate tendency of 20 and $36 \%$, respectively (Table 1 ). According to the test ( $p$ $<0.05$ ), only the BREB method presented no difference in relation to the $\mathrm{EC}$ method.

The values mentioned in the present study are in agreement with those observed for canopy forest in China, where RMSE and "b" were $61.4 \mathrm{~W} \mathrm{~m}^{-2}$ and 0.80 , respectively, which were also reported an underestimate of BREB in relation to EC (Shi et al., 2008). In relative terms, EC measures tend to favor $H$, while BREB estimates favor $\lambda E$ (Barr et al., 1994). This disparity between EC and BREB can be attributed to the $\lambda E$ correction procedures, which tend to increase these fluxes disproportionately in relation to $\mathrm{H}$, with direct effect on the $H / \lambda E(\lambda)$ ratio of $E C$ (Wolf et al., 2008).

\section{Temporal pattern of daily evapotranspiration}

The ET daily course considered two specific days, one with clear sky and one partially cloudy. It indicated the same daily variation among methods (Fig. 3). Considering EC, maximum ET occurred at $13.5 \mathrm{~h}\left(0.33 \mathrm{~mm} 30 \mathrm{~min}^{-1}\right)$ and $11.5 \mathrm{~h}(0.38$ $\mathrm{mm} 30 \mathrm{~min}^{-1}$ ) during days July 20th (partly cloudy) and July 27th 2013 (clear sky), respectively (Fig. 3A). For the EC_R method, ET peaks were observed at $13.5 \mathrm{~h}$ on July 20th $(0.39$

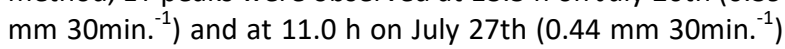
(Fig 3B). By the BERB method, during July 20th and July 27 th, ET peaks were recorded at $13.5 \mathrm{~h}\left(0.31 \mathrm{~mm} 30 \mathrm{~min}^{-1}\right)$ and $11.5 \mathrm{~h} \quad\left(0.31 \mathrm{~mm} 30 \mathrm{~min}^{-1}\right)$ (Fig. 3C), respectively. Considering BREB_S, maximum ET occurred at $13.5 \mathrm{~h}(0.40$ $\left.\mathrm{mm} 30 \mathrm{~min}^{-1}\right)$ on July 20th and $11.5 \mathrm{~h}\left(0.45 \mathrm{~mm} 30 \mathrm{~min}^{-1}\right)$ on July $27^{\text {th }}$, respectively (Fig. 4D).

The daily ET was evaluated from values accumulated during the days, in which EC determinations were valid. By the EC, the accumulation was $122.5 \mathrm{~mm}$, with an average of $4.0 \mathrm{~mm}$ 
Table 1. Wilmott's index of agreement (d), root mean square error (RMSE), slope coefficient (b) and Student's test ( $t$ ) for the Bowen ratio - energy balance (BREB), Bowen ratio - energy balance with surface temperature and residual Eddy covariance technique $\left(E C \_R\right)$ in relation to the eddy covariance technique (EC). Mean evapotranspiration (ETa) and relationship with reference evapotranspiration $\left(\mathrm{ET}_{0}\right)$.

\begin{tabular}{llllll}
\hline Method & \multicolumn{3}{l}{ Statistic index } & \multicolumn{2}{l}{ Evapotranspiration } \\
\cline { 2 - 6 } & $\mathrm{d}$ & $\mathrm{RMSE}\left(\mathrm{W} \mathrm{m}{ }^{-2}\right)$ & $\mathrm{b}$ & $\mathrm{ETa}\left(\mathrm{mm} \mathrm{d}^{-1}\right)$ & $\mathrm{ET}^{-1} \mathrm{ET}_{0}$ \\
\hline EC & - & - & - & 4.0 & 0.89 \\
BREB & 0.97 & 62.1 & $1.06^{\text {n.s. }}$ & 4.2 & 0.96 \\
BREB_S & 0.90 & 130.9 & $1.36^{*}$ & 5.4 & 1.22 \\
EC_R & 0.96 & 77.1 & $1.20^{*}$ & 4.6 & 1.04 \\
\hline
\end{tabular}

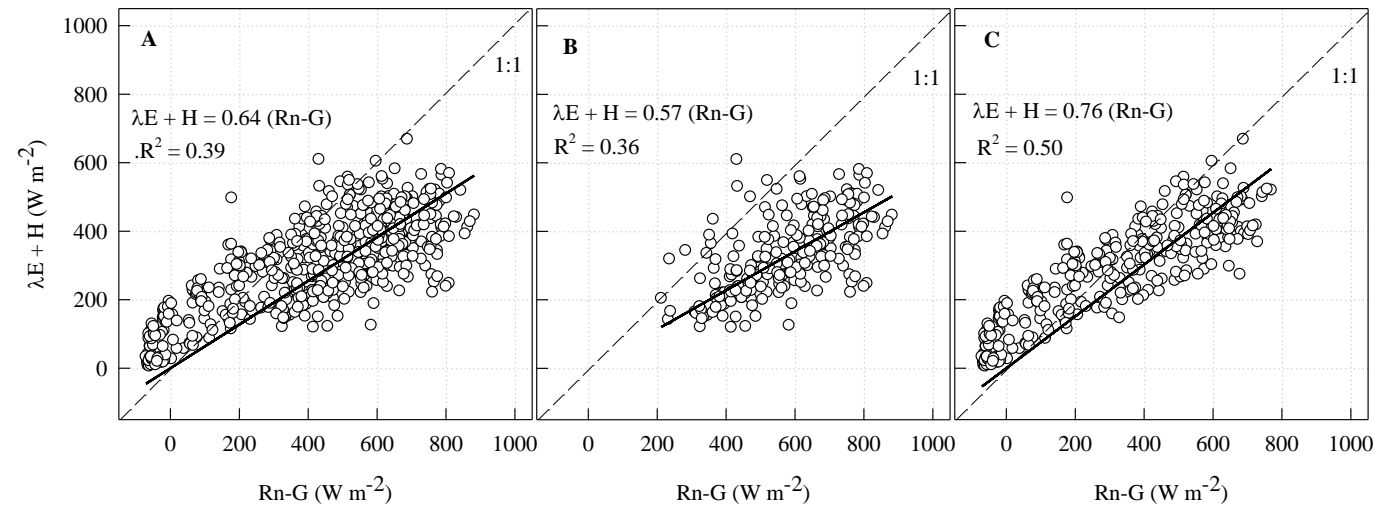

Fig 1. Energy balance closure by the Eddy covariance technique considering total daytime (A), morning (B) and afternoon fluxes (C) during sugarcane cultivation. Latent $(\lambda E)$ and sensible heat flux $(H)$, net radiation $(R n)$ and soil heat flux $(G)$.

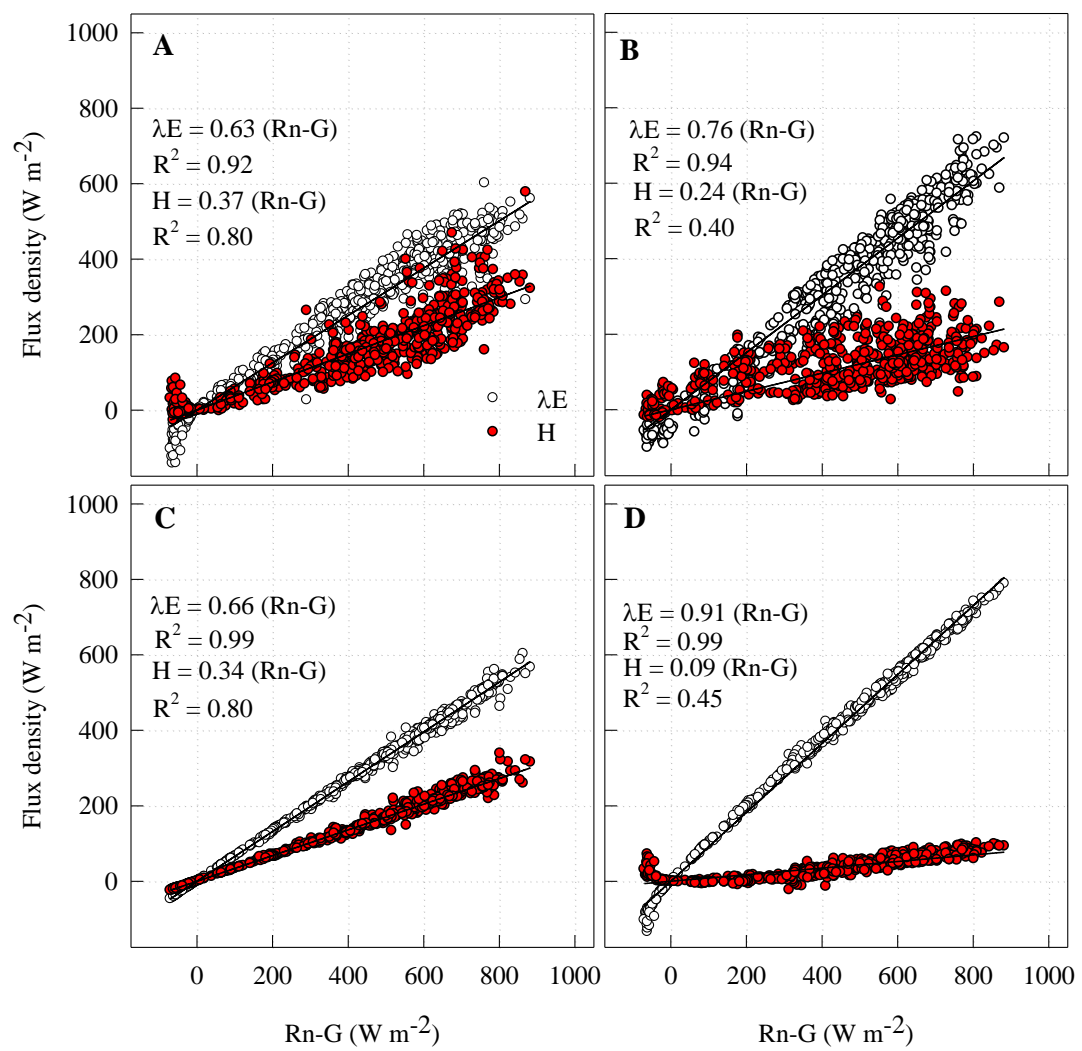

Fig 2. Partition of the available energy $(\mathrm{Rn}-\mathrm{G})$ during sugarcane cultivation between latent $(\lambda E)$ and sensitive heat flux $(H)$ with Eddy covariance technique - EC (A), residual eddy covariance technique EC_R (B), Bowen ratio- energy balance - BREB (C) and Bowen ratio - energy balance with surface temperature - BREB_S (D). 


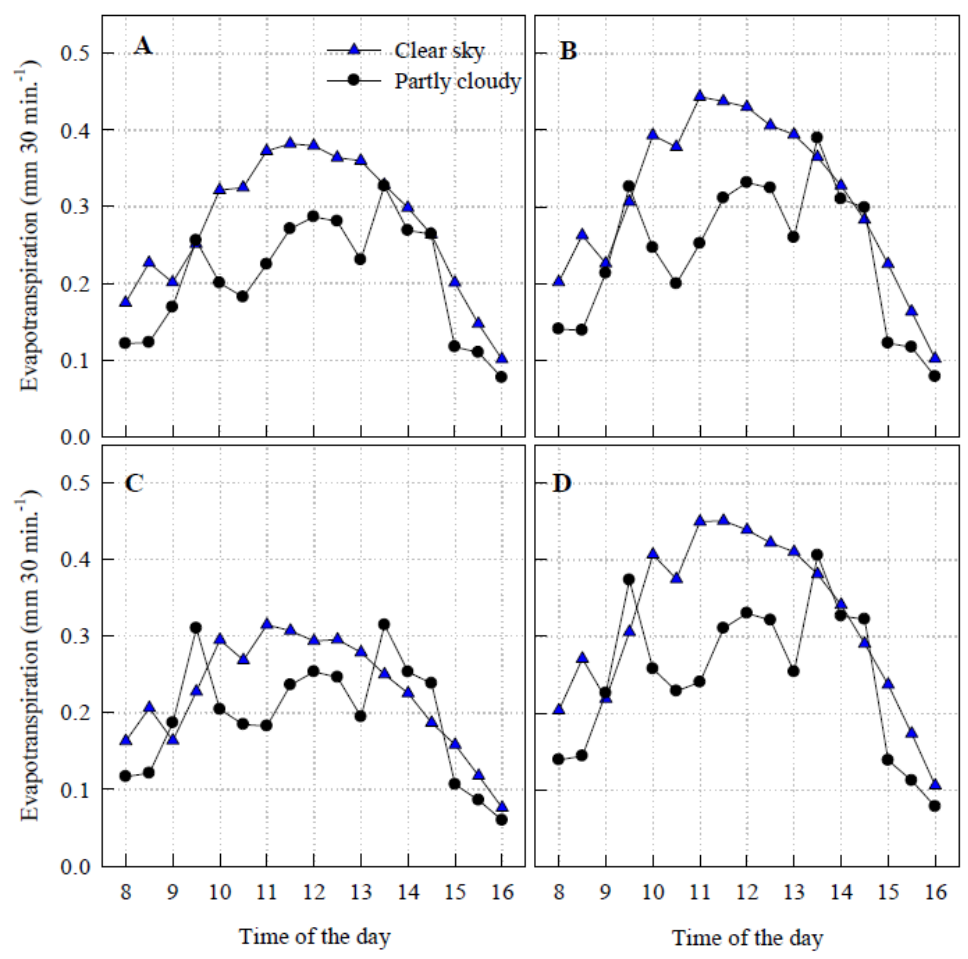

Fig 3. Instantaneous evapotranspiration of sugarcane during the days $07 / 20$ (partly cloudy) and $07 / 27 / 2013$ (clear sky) with Eddy covariance technique - EC (A), residual eddy covariance technique - EC_R (B), Bowen ratio - energy balance - BREB (C) and Bowen ratio - energy balance with surface temperature - BREB_S (D) methods.

$\mathrm{d}^{-1}$, which resulted in $E T / E T_{0}$ ratio of 0.89 , close to estimates by the BREB method, which presented total ET of $131.5 \mathrm{~mm}$, mean of $4.2 \mathrm{~mm} \mathrm{~d}^{-1}$ and $E T / E T_{0}$ ratio of 0.96 . Estimates by EC_R and BREB_S methods show a larger difference from observations, with averages of 4.6 and $5.4 \mathrm{~mm} \mathrm{~d}^{-1}$ and $\mathrm{ET} / \mathrm{ET}_{0}$ ratios of 1.22 and 1.04, respectively (Table 1).

Regarding BREB, the values agree with those reported by Nassif et al. (2014) for sugarcane in the region of São Paulo, Brazil, where the mean $\mathrm{ET} / \mathrm{ET}_{0}$ ratio was 0.87 , with a variation between 0.9 and 1.1. Silva et al. (2012) reported mean $\mathrm{ET}$ of $4.7 \mathrm{~mm} \mathrm{~d}^{-1}$, with $\mathrm{ET} / \mathrm{ET}_{0}$ ratios between 0.65 and 1.10 using BREB in the Brazilian semi-arid. ET obtained by EC was superior to that reported by Denmead et al. (2009) in two regions of Australia, where the mean ranged from 3.3 to $3.7 \mathrm{~mm} \mathrm{~d}^{-1}$.

\section{Materials and methods}

\section{Experimental area and plant materials}

Micrometeorological measurements were conducted between June 7th and November 17th, 2013 in commercial sugarcane growing area (17.1 ha) $\left(9^{\circ} 28^{\prime} 04^{\prime \prime} S, 35^{\circ} 47^{\prime} 34^{\prime \prime} \mathrm{W}\right.$ and $137 \mathrm{~m}$ ), sugarcane plant cycle, cultivar RB867515, with planting carried out on March 25, 2013. The climate of the region, according to the Thornthwaite and Matter method, is characterized as humid, megathermal, with great water excess in the winter and moderate deficiency in the summer. The average annual rainfall is $1789 \mathrm{~mm}$, with air temperature and relative humidity of $25.4{ }^{\circ} \mathrm{C}$ and $81.8 \%$, respectively. The soil is classified as Yellow Latosol with medium-clay texture and flat topography (Ferreira Junior et al., 2014).

\section{Radiometric measurements}

Measurements to determine the net radiation ( $R n)$ were obtained by a net radiometer installed above the crop canopy (CNR1, Kipp and Zonen, The Netherlands) and connected to an automatic data acquisition system (CR1000, Campbell Scientific Inc., Logan, USA) programmed to record the radiation every 10 seconds and store averages every 5 min. The short-wave balance (SWB) was obtained by the difference between global $(\mathrm{Rg})$ and reflected solar irradiance (Rr). The long-wave balance (LWB) was determined by the difference between surface (Rs) and atmosphere emittance (Ra). Subsequently, $\mathrm{Rn}$ was calculated by the difference between SWB and LWB (Allen et al., 1998). The daily clearness index $(\mathrm{Kt})$ was determined through the ratio between global solar radiation $(\mathrm{Hg})$ and extraterrestrial solar radiation (Ho) (Allen et al., 1998) by adopting the following classification: $\mathrm{Kt} \leq 0.3$ - cloudy sky, $0.3<\mathrm{Kt}<0.7$ - partly cloudy sky and Kt $\geq 0.7$ - clear sky (lqbal, 1983).

\section{Eddy covariance technique (EC)}

The eddy covariance system (EC) was installed in the center of the crop in the predominant wind direction with fetch above 1:100 $\mathrm{m}$. Vertical wind fluctuations and sonic temperature were measured using a three-dimensional sonic anemometer (CSAT3A 3D, Campbell Scientific Inc., Logan, USA). The water vapour concentration was quantified using an infrared gas analyzer (EC150, Campbell Scientific Inc., Logan, USA). In both devices, data were obtained at a frequency of $10 \mathrm{~Hz}$ and corrected for density effects due to the transfer of water vapour and heat (Webb et al., 1980). $\lambda \mathrm{E}$ and $\mathrm{H}$ fluxes were determined by the covariance between vertical wind fluctuations and water vapour concentration or 
sonic temperature fluctuations, respectively, in averages of 30 min (Baldocchi, 2003; Li et al., 2008).

The quality of the measurements of fluxes by EC was quantified by the degree of energy balance closure (EBC), represented by the relationship between output fluxes $(\lambda E+$ $\mathrm{H})$ and the available energy ( $\mathrm{Rn}-\mathrm{G})$. The data obtained by the EC were submitted to quality control, with the exclusion of physically inconsistent data, during rainfall events and malfunctioning of the EC equipment (Hernandez-Ramirez et al., 2010; Schmidt et al., 2012). For comparison purpose, $\lambda E$ was also calculated as the residue (EC_R) of the energy balance equation $(\lambda E=R n-G-H)$, considering the $H$ values of EC and soil heat fluxes densities (G) (Twine et al., 2000), which estimated of $\mathrm{Rn}(1.4 \%)$. This represents the average value obtained from sugarcane studies in the region (Santos, 2009).

\section{Bowen ratio-energy balance method (BREB)}

We estimated the Bowen ratio - energy balance, in addition to determining $\lambda E$ by $E C$ and EC_R methods (Bowen, 1926). Thus, two air temperature and relative humidity sensors (HMP45C, Campbell Scientific, Logan, Utah) were installed at two levels above the vegetated surface. The first one at 0.25 $\mathrm{m}$ above the crop canopy and the second one at $3.20 \mathrm{~m}$ from the first. The Bowen ratio $(\beta)$ was determined by the following equation:

$$
\beta=\frac{\mathrm{H}}{\lambda \mathrm{E}}=\gamma \frac{\Delta \mathrm{T}}{\Delta \mathrm{e}}=\gamma \frac{\mathrm{t}_{1}-\mathrm{t}_{2}}{\mathrm{ea}_{1}-\mathrm{ea}_{2}}
$$

where: $\Delta T$ and $\Delta \mathrm{e}$ represent the difference of air temperature and the current air-water vapour pressure $(\mathrm{kPa})$ between the two measurement levels, respectively; $t_{1}$ and $t_{2}$ indicate the air temperature $\left({ }^{\circ} \mathrm{C}\right)$ at levels 1 and 2 , respectively; $\gamma=c_{p} P / \varepsilon \lambda$ is the psychrometric coefficient; $P$ is the atmospheric pressure $(\mathrm{kPa}) ; \varepsilon$ is the molecular weight ratio of dry air water vapour (0.622); $\mathrm{ea}_{1}$ and $\mathrm{ea}_{2}$ are the current water vapour pressures at levels 1 and $2(\mathrm{kPa})$, respectively (Allen et al. 1998). $\lambda \mathrm{E}$ and $\mathrm{H}$ fluxes by BREB were calculated by the following equations:

$$
\begin{aligned}
& \lambda E=\frac{R n-G}{1+\beta} \\
& H=\frac{\beta}{1+\beta}(R n-G)
\end{aligned}
$$

The consistency analysis of data provided by BREB was based on Unland et al. (1996), who recommends data exclusion when the absolute difference between air water vapour pressures of the two measurement levels is less than $0.005 \mathrm{kPa}$ and $\beta$ values close to -1 , specifically for the range of $|1+\beta|<0.3$.

\section{Bowen ratio-energy balance method with surface temperature (BREB)}

The BREB method was also applied considering the surface temperature obtained by radiometric measurements (BREB_S), according to Penman (1948):
$\beta=\frac{\mathrm{H}}{\lambda \mathrm{E}}=\gamma \frac{\Delta \mathrm{T}}{\Delta \mathrm{e}}=\gamma \frac{\mathrm{t}_{\mathrm{o}}-\mathrm{t}_{2}}{\mathrm{es}_{\mathrm{o}}-\mathrm{ea}_{2}}$

Where; $\mathrm{es}_{0}$ is the saturation vapour pressure $(\mathrm{kPa})$ obtained by radiometric measurements and $t_{0}$ is the surface temperature $\left({ }^{\circ} \mathrm{C}\right)$, determined from the following equation:

$\mathrm{t}_{0}=\sqrt[4]{\frac{\mathrm{E}_{0}}{\varepsilon_{0} \sigma}}$

Where; $E_{0}$ is the emittance of the sugarcane canopy $\left(\mathrm{W} \mathrm{m}^{-2}\right)$; $\varepsilon_{0}$ is the emissivity of sugarcane leaves, 0.995 (Idso et al., 1969); $\sigma$ is the Stefan-Boltzman constant $\left(5.6710^{-8} \mathrm{~W} \mathrm{~m}^{-2} \mathrm{~K}\right.$ $\left.{ }^{4}\right)$. At the end, the instantaneous $\lambda E$ values were integrated (MJ $\mathrm{m}^{-2} \mathrm{day}^{-1}$ ) and the sugarcane ET ( $\mathrm{mm}$ day ${ }^{-1}$ ) was calculated by the division between $\lambda \mathrm{E}$ and the water vaporization latent heat $\left(2.45 \mathrm{MJ} \mathrm{kg}^{-1}\right)$.

The daily reference evapotranspiration $\left(\mathrm{ET}_{\mathrm{o}}, \mathrm{mm} \mathrm{d}^{-1}\right)$ was determined by the Penman-Monteith-FAO method, parameterized to a hypothetical culture, as described in FAO Bulletin No. 56 (Allen et al., 1998):

$$
\mathrm{ET}_{0}=\frac{0,408 \Delta(\mathrm{Rn}-\mathrm{G})+\left(\gamma \frac{900}{\mathrm{~T}+273}\right) \mathrm{u}_{2}\left(\mathrm{e}_{\mathrm{s}}-\mathrm{e}_{\mathrm{a}}\right)}{\Delta+\left[\gamma(1+0,34) \mathrm{u}_{2}\right]}
$$

Where; $\mathrm{u}_{2}$ is the wind speed at $2 \mathrm{~m}$ height $\left(\mathrm{m} \mathrm{s}^{-1}\right) ; \mathrm{T}$ is the air temperature at $2 \mathrm{~m}$ height $\left({ }^{\circ} \mathrm{C}\right) ; \mathrm{e}_{\mathrm{s}}$ is the air-water saturation vapour pressure $(\mathrm{kPa})$; and $\Delta$ is the slope vapour pressure $\left(\mathrm{kPa}{ }^{\circ} \mathrm{C}^{-1}\right)$. Meteorological data required for the determination of $\mathrm{ET}_{0}$ were obtained from the automatic agrometeorological station (Campbell Scientific, Logan, Utah, USA) located close to the field area.

\section{Statistical analysis}

The comparison of $\lambda E$ values was based on statistical index and considered the fluxes determined by EC as the standard (observed). The accuracy was represented by Root Mean Square Error (RMSE) and Wilmott's index of agreement (d), which varies between 0 and 1 , and the closer to 1 , the greater the approximation between estimated and observed data (Willmott, 1982). The tendency of estimates in relation to the observations was determined by the slope (b) forced to pass through the origin and the precision evaluated by determination coefficient $\left(r^{2}\right)$. The Student's test $(t)$ ( $p<$ 0.05 ) was used to verify difference between estimated and observed means.

\section{Conclusions}

The energy balance closure using the Eddy covariance technique showed higher value during the afternoon than in the morning. Latent heat flux estimates by the energy balance - Bowen ratio were closer to fluxes obtained by the Eddy covariance technique, followed by the residual Eddy covariance technique. 


\section{Acknowledgements}

The authors would like to thank the Coordination for the Improvement of Higher Education Personnel (CAPES) for the scholarships and Santa Clotilde Plant S/A for offering the study area.

\section{References}

Allen RG, Pereira LS, Raes D, Smith M (1998) Crop evapotranspiration-Guidelines for computing crop water requirements-FAO Irrigation and drainage paper 56. - FAO. 300: D05109.

Azevedo PV, Saboya LM, Neto JD, Oliveira FDS, Bezerra JR, Carlos HDA (2014) Disponibilidade energética para a cultura da cana-de-açúcar nos tabuleiros costeiros do estado da Paraíba. Rev Bras Eng Agríc. 18: 1031-1038.

Baldocchi DD, Hincks BB, Meyers TP (1988) Measuring biosphere-atmosphere exchanges of biologically related gases with micrometeorological methods. Ecol. 69: 13311340.

Baldocchi DA (2003) Assessing the eddy covariance technique for evaluating carbon dioxide exchange rates of ecosystems: past, present and future. Global Change Biol. 9: 479-492.

Barr AG, King KM, Gillespie TJ, Den Hartog G, Neumann HH (1994) A comparison of Bowen ratio and eddy correlation sensible and latent heat flux measurements above deciduous forest. Boundary-Layer Meteorol. 71: 21-41.

Bowen IS (1926) The ratio of heat losses by conduction and by evaporation from any water surface. Phys Rev. 27: 779787.

Cabral OMR, Rocha HR, Ligo MAV, Brunini O, Dias MAFS (2003) Fluxos turbulentos de calor sensível, vapor d'água e $\mathrm{CO}_{2}$ sobre plantação de cana-de-açúcar (Saccharum sp.) em Sertãozinho-SP. Rev Bras Eng Agríc, 18: 61-70, 2003.

Chávez JL, Howell TA, Copeland KS (2009) Evaluating eddy covariance cotton ET measurements in an advective environment with large weighing lysimeters. Irrig Sci. 28: 35-50.

Denmead OT, Macdonald BCT, White I, Griffith DWT, Bryant G, Naylor T, Wilson SR (2002) How plants cope with water stress in the field? Photosynthesis and growth. Ann Bot. 89: 907-916, 2002.

Ding R, Kang S, Li F, Zhang Y, Tong L, Sun Q (2010) Evaluating eddy covariance method by large-scale weighing lysimeter in a maize field of northwest China. Agric Water Manag. 98: 87-95.

Er-Raki S, Rodriguez JC, Garatuza-Payan J, Watts CJ, Chehbouni A (2013) Determination of crop evapotranspiration of table grapes in a semi-arid region of Northwest Mexico using multi-spectral vegetation index. Agric Water Manag. 122: 12-19.

Ferreira Junior RA, Souza JL, Escobedo JF, Teodoro I, Lyra GB, Araújo Neto RA (2014) Cana-de-açúcar com irrigação por gotejamento em dois espaçamentos entrelinhas de plantio. Rev Bras Eng Agríc. 18: 798-804.

Foken T, Wimmer F, Mauder M, Thomas C, Liebethal C (2006) Some aspects of the energy balance closure problem. Atmos Chem Phys. 6: 4395-4402.
Hernandez-Ramirez G, Hatfield JL, Prueger JH, Sauer TJ (2010) Energy balance and turbulent flux partitioning in a corn-soybean rotation in the Midwestern US. Theor Appl Climatol. 100: 79-92.

Idso SB, Jackson RD, Ehrler WL, Mitchell ST (1969) A method for determination of infrared emittance of leaves. Ecol. 50: 899-902.

Iqbal M (1983) An introduction to solar radiation. New York: Academic Press, 390pp.

Jabloun M, Sahli A (2008) Evaluation of FAO-56 methodology for estimating reference evapotranspiration using limited climatic data: Application to Tunisia. Agric Water Manag. 95: 707-715.

Lhomme JP, Monteny B, Madou M (1994) Estimating sensible heat flux from radiometric temperature over sparse millet. Agric For Meteorol. 68: 77-91.

Li Z, Yu G, Wen X, Zhang L, Ren C, Fu Y (2005) Energy balance closure at ChinaFLUX sites. Science in China Series D-Earth Sciences, 48: 51-52.

Li S, Kang S, Li F, Hang L (2008) Evapotranspiration and crop coefficient of spring maize with plastic mulch using eddy covariance in northwest China. Agric Water Manag. 95: 1214-1222.

Liu G, Haffez M, Liu Y, Xu D, Vote C (2012) A novel method to convert daytime evapotranspiration into daily evapotranspiration based on variable canopy resistance. J Hydrol. 414: 278-283.

Mauder M, Cuntz M, Drue C, Graf A, Rebmann, C, Schmidt, M, Steinbrecher, R (2013) A strategy for quality and uncertainty assessment of long-term eddy-covariance measurements. Agric For Meteorol. 169:122-135.

Meyers TP, Hollinger, SE (2004) An assessment of storage terms in the surface energy balance of maize and soybean. Agric For Meteorol. 125: 105-115.

Nassif, DSP, Marin, FR, Costa, LG (2014) Evapotranspiration and transpiration coupling to the atmosphere of sugarcane in southern Brazil: scaling up from leaf to field. Sugar Tech. 16: $250-254$.

Norman, JM, Kustas, WP, Prueger, JH, Diak, GR (2000) Surface flux estimation using radiometric temperature: $A$ dual-temperature-difference method to minimize measurement errors. Water Resources Res. 36:2263-2274.

Ohmura, A (1982) Objective criteria for rejecting data for Bowen ratio flux calculations. J Appl Meteorol. 21: 595598.

Oncley SP, Foken T, Vogt R, Kohsiek $W$, de Bruin $H$, Bernhofer C, Christen A, Grantz D, Lehner E, Liebethal C, Liu H, Mauder M, Pitacco A, Ribeiro L, Weidinger T (2007) The energy balance experiment EBEX-2000. Part I: Overview and energy balance. Boundary-Layer Meteorol. 123: 1-28.

Parent, AC, Anctil, $f$ (2012) Quantifying evapotranspiration of a rainfed potato crop in South-eastern Canada using eddy covariance techniques. Agric Water Manag. 113, p. 45-56.

Penman, HL (1948) Natural evaporation from open water, bare soil and grass. In: Proceedings of the Royal Society of London A: Mathematical, Physical and Engineering Sciences. The Royal Society. 120-145.

Rocha AEQ, Souza JL, GB Bastos Lyra, Ferreira Junior RA, Lyra BG, Endres L, Santos MVC (2018) Water vapour and carbon dioxide fluxes in sugarcane grown in megathermal humid climate in Northeastern Brazil. Aust J Crop Sci. 12:755-762 
Sànchez JM, Caselles V, Niclòs R, Coll C, Kustas WP (2009) estimating energy balance fluxes above a boreal forest from radiometric temperature observations. Agric For Meteorol. 149: 1037-1049.

Santos MA (2010) Balanço de radiação, energia e água em cana-de-açúcar na região dos Tabuleiros Costeiros de Alagoas. 2010. 57f. Trabalho de conclusão de curso (Graduação em Agronomia) - Universidade Federal de Alagoas, Maceió.

Schmidt M, Reichenau TG, Fiener P, Schneider K (2012) The carbon budget of a winter wheat field: An eddy covariance analysis of seasonal and inter-annual variability. Agric For Meteorol. 165: 114-126.

Silva TG, Moura MS, Zolnier S, Soares JM, Souza LS, Brandão EO (2011) Variação do balanço de radiação e de energia da cana-de-açúcar irrigada no semiárido brasileiro. Rev Bras Eng Agríc. 15: 139-147.

Silva TG, Moura MS, Zolnier S, Soares JM, Vieira VJDS, Júnior WGF (2012) Requerimento hídrico e coeficiente de cultura da cana-de-açúcar irrigada no semiárido brasileiro. Rev Bras Eng Agríc. 16: 64-71.

Silva VPD, Oliveira SD, Santos CA, Silva MT (2013) Risco climático da cana-de-açúcar cultivada na região nordeste de Brasil. Rev Bras Eng Agríc. 17: 180-189.

Silva VPD, Garcêz SL, Silva BB, Albuquerque MF, Almeida RSS (2015) Métodos de estimativa da evapotranspiração da cultura da cana-de-açúcar em condições de sequeiro. Risco climático da cana-de-açúcar cultivada na região nordeste de Brasil. Rev Bras Eng Agríc. 19: 411-417.

Shi TT, Guan DX, Wu JB, Wang AZ, Jin CJ, Han SJ (2008) Comparison of methods for estimating evapotranspiration rate of dry forest canopy: Eddy covariance, Bowen ratio energy balance, and Penman-Monteith equation. J Geophys Res-Atmos. D19: 1-15

Steinwand AL, Harrington RF, OR D (2006) Water balance for great basin phreatophytes derived from eddy covariance, soil water, and water table measurements. J Hydrol. 329: 595-605.
Teodoro I, Dantas Neto J, Holanda LA, Sampaio Neto GD, Souza JL, Barbosa GVS, Lyra GB (2015) Weather variables, water balance, growth, and agro industrial yield of sugarcane. Eng Agríc. 35: 76-88.

Twine TE, Kustas WP, Norman JM, Cook DR, Houser PR, Meyers TP, Prueger JH, Starks PJ, Wesely ML (2000) correcting eddy-covariance flux underestimates over a grassland. Agric For Meteorol. 103: 279-300.

Unland HE, Houser PR, Shuttheworth WJ, Yang ZL (1996) Surface flux measurement and modeling at a semi-arid Sonoran Desert site. Agric For Meteorol. 82: 119-153.

Webb EK, Pearman GI Leuning R (1980) Correction of flux measurements for density effects due to heat and water vapour transfer. Quart J Roy Meteorol Soc. 106: 85-100.

Willmott CJ (1982) Some comments on the evaluation of model performance. Bull Amer Meteor Soc. 63: 13091313.

Wilson KB, Hanson PJ, Mulholland PJ, Baldocchi, DD, Wullschleger SD (2001) A comparison of methods for determining forest evapotranspiration and its components: sap-flow, soil water budget, eddy covariance and catchment water balance. Agric For Meteorol. 106: 153-168.

Wilson $K$, Falge $E$, Aubinet $M$, Baldocchi D, Goldstein A, Berbigier P (2002) Energy balance closure at FLUXNET sites. Agric For Meteorol 113:223-243 Energy balance closure at FLUXNET sites. Agric For Meteorol. 113: 223243.

Wolf A, Saliendra N, Akshalov K, Johnson, DA Laca, E (2008) Effects of different eddy covariance correction schemes on energy balance closure and comparisons with the modified Bowen ratio system. Agric For Meteorol. 148: 942-952.

Zermeño-González A, Villatoro-Moteno S, Cortés-Bracho JJ, Cadena-Zapata M, Catalán-Valencia EA, García-Delgado MA, Munguía-López JP (2012) estimación del intercambio neto de $\mathrm{CO}_{2}$ en un cultivo de caña de azúcar durante el ciclo de plantilla. Agroc. 46: 579-591. 